\title{
Diagnostic and Prognostic Significance of Neutrophil Gelatinase- Associated Lipocalin and Pentraxin-3 in Acute Coronary Syndrome
}

\author{
Muhammet Raşit Özer', Mehmet Ergin', İbrahim Kılınç², Zerrin Defne Dündar', Nejla Özer², Mehmet Akif Önal' , Abdullah Sadık Girişgin'1, \\ Sedat Koçak', Mehmet Gül', Başar Cander ${ }^{1}$ \\ 'Department of Emergency Medicine, Necmettin Erbakan University School of Medicine, Konya, Turkey \\ 2Department of Biochemistry, Necmettin Erbakan University School of Medicine, Konya, Turkey
}

\begin{abstract}
Aim: The aim was to evaluate the levels of serum pentraxin-3 (PTX-3) and neutrophil gelatinase-associated lipocalin (NGAL) and the efficiency of making a diagnosis and to estimate the prognosis in patients with chest pain.

Materials and Methods: The study was conducted in the Necmettin Erbakan University Meram Medicine School Emergency Department. Patients who had chest pain and met the inclusion criteria were accepted. They were divided into the following groups: acute coronary syndrome (ACS), a diagnosis other than ACS (non-ACS), and control. The patients in theACS and non-ACS groups were divided into five sub-group -groups: ST Elevated Myocardial Infarction (STEMI) Non- ST Elevated Myocardial Infarction (NSTEMI), Unstable Angina Pectoris (USAP), stable angina, and pulmonary embolus. For all patients, serum PTX-3, serum NGAL, troponin I, and creatine kinase-MB fraction (CK-MB) levels were measured.

Results: There were 199 patients in the ACS and non-ACS groups and 30 patientsin the control group. There was no significant difference among the study groups in terms of age and PTX-3 and NGAL levels. When comparing survival and non-survival in terms of in-hospital death, CK-MB and troponin I levels were significantly higher in the ACS and non-ACS groups than in the control groups, whereas there was no significant difference in terms of PTX-3 and NGAL levels.

Conclusion: The results of our study demonstrated that PTX-3 and NGAL are not effective biomarkers in the differential diagnosis and the determination of in-hospital mortality in ACS. However, the limitations of the study should be considered. The results confirmed that CK-MB and Troponin I can be safely used in the differential diagnosis and the prediction of mortality.
\end{abstract}

Keywords: Acute coronary syndrome, biomarker, neutrophil gelatinase-associated lipocalin, pentraxin-3

\section{Introduction}

Chest pain is one of the main reasons for admission to emergency departments (EDs). Among patients with such admissions, 30\% to $50 \%$ have acute coronary syndrome (ACS). Coronary artery disease (CAD) is the most common cardiovascular diseases and is related to high mortality rates $(1,2)$.

Chest pain-related admissions to EDs are important ongoing problem for physicians. Despite the clinical experience of physicians and presence of electrocardiogram (ECG) and biochemical parameters, $2 \%-5 \%$ of patients with ACS remain undiagnosed (3). Cardiac troponin is a highly sensitive and specific biomarker that demonstrates myocardial damage. However, it is not specific as high levels of it can also be detected in many clinical conditions (renal failure, gastrointestinal bleeding, respiratory disease, subarachnoid hemorrhage and ischemic stroke) other than ACS (4-8). In spite of this, cardiac troponins have recently been accepted as the gold standard biomarker in ischemic myocardial damage (9).

Pentraxin-3 (PTX-3) and neutrophil gelatinase-associated lipocalin (NGAL) are believed to be involved in the pathophysiology of ACS (10). It has been reported that PTX-3 is secreted from cardiomyocytes in cardiac ischemia and that it is anindicator of myocyte injury. PTX-3 has also been reported to appear with acute myocardial infarction (AMI), which reaches its peak level at the seventh hour, regresses within several days, and finally returns to its normal plasma level (11). NGAL has been shown to be primarily produced in neutrophils and

This study was presented at the $11^{\text {th }}$ National Emergency Medicine Congress and $2^{\text {nd }}$ Intercontinental Emergency Medicine Congress, 16-19 April, Antalya, Turkey.

Correspondence to: Muhammet Raşit Özer e-mail:drrasitozer@gmail.com 
subsequently in cardiomyocytes, and its levels are elevated in pathological conditions such as atherosclerosis (12-16).

The aim of this study was to investigate whether the new-generation biomarkers NGAL and PTX-3 have a diagnostic value superior to the routinely used biomarkers CK-MB and troponin I in patients suspected of having ACS and to determine the relationship of these biomarkers with hospital mortality rates.

\section{Materials and Methods}

The Ethics Committee of Necmettin Erbakan University Meram Medicine School approved this controlled prospective clinical study on January 3, 2014 (number, 2014-570). This study included 229 patients who met with the inclusion criteria, who had presented to the Necmettin Erbakan University Meram Medicine School Emergency Department (ED) with chest pain and equivalent complaints, and who were followed up with a pre-diagnosis of ACS in the ED.

\section{Study groups}

Group 1 included patients with ACS (including MI with ST segment elevation (STEMI), MI with non-STEMI (NSTEMI), and unstable angina pectoris (USAP)]; Group 2 included patients with a diagnosis other than ACS (non-ACS) (including pulmonary embolism and stable angina), and Group 3 was the control group, which included patients with a diagnosis other than ACS or non-ACS. The patients were consecutively enrolled. Cardiac biomarkers were evaluated between survival and non-survival groups.

\section{Study protocol}

Patients who had presented to the ED with chest pain and who had agreed to participate were physically examined by an emergency physician (EP) and underwent electrocardiography; then, they were taken to the chest pain unit (CPU) for follow-up. The investigators analyzed the patients who were taken to the CPU for compatibility with the inclusion criteria, informed the proper patients, and obtained their consents (Table 1). The demographic characteristics, contact information, and laboratory and radiological examinations requested by the EP were recorded. NGAL and PTX-3 levels of the patients were also determined. The patients were followed up, and their in-hospital clinical courses were recorded.

Table 1. Inclusion and exclusion criteria of patients in the study

\begin{tabular}{|l|}
\hline A. Inclusion criteria \\
\hline 1. Patients who were $\geq 18$ years of age \\
\hline 2. Patients who agreed to join the study \\
\hline 3. Admission to the ED with chest pain or equivalent compla- \\
ints \\
\hline B. Exclusion criteria \\
\hline 1. Female patients who were pregnant or breast feeding \\
\hline 2. Patients who were $<18$ years age \\
\hline 3. Patients who refused to join the study \\
\hline 4. Patients with a history of chronic renal failure \\
\hline 5. Patients who had a history of active or previous cancer \\
\hline ED: emergency department \\
\hline
\end{tabular}

\section{Biochemical evaluation}

Having performed tests for the differential diagnosis of chest pain, the sera and plasma of the venous blood drawn at admission from the included patients were used as samples. Blood samples were centrifuged at $4000 \mathrm{~g}$ for $5 \mathrm{~min}$. The blood samples to be analyzed for N-GAL and PTX-3 level were transferred into plastic and sealed Eppendorf tubes and storedat $-80^{\circ} \mathrm{C}$ until biochemical analysis. On the day of analysis, they were obtained from the Eppendorf tubes and incubated at room temperature and analyzed. NGAL (Lot no: 5031059529) (Boster ${ }^{\circledR}$, USA) and PTX-3 (Lot no: 5111059529) (Boster ${ }^{\oplus}$, USA) levels were determined by ELISA using ELISA kits. An ELISA washer and a semi-automatic ELISA reader were used. CK-MB and troponinl levels were analyzed using a Beckman Coulter DXI 800 instrument by the chemiluminescence method.

\section{Statistical analysis}

The data obtained were analyzed using Statistical Package For Social Sciences version 16.0 (SPSS Inc.; Chicago, Illinois, ABD). Descriptive data are expressed as mean \pm standard deviation and percentage. Normally distributed data (parametric or non-parametric) were analyzed using the Kolmogorov-Smirnov Test. Non-normally distributed variables were expressed as median \pm the interval between quarters (25\%75\%). The Mann-Whitney $U$ and Kruskal-Wallis tests were used for the comparison of non-parametric variables. The chi-square test was used to determine the significance of the differences among the patient and control groups with regard to the demographic characteristics and comorbid situations. The Pearson test was used for correlation analysis. A $p$ value of $<0.05$ was accepted as statistically significant.

\section{Results}

A total of 229 patients were included (Table 2). Their mean age was $60.48 \pm 14.84$ years. A statistically significant difference was observed among the groups with regard to the mean age $(p=0.001)$. The mean age in patients in Group 2 was lower than those patients in the other groups. Totally, $69 \%(n=158)$ of the patients were males and $31 \%(n=71)$ were females. No difference was observed amongthe groups with regard to gender distribution $(p=0.353)$. The number of patients with an additional disease in Group 1 was significantly higher than that in the other groups $(p=0.001)$. The number of patients with an atherosclerotic cardiac disease was significantly higher in Group 1 than in the other groups $(p=0.013)$. No difference was observed among the groups with regard to the history of diabetes mellitus, hypertension, hyperlipidemia, and smoking $(p=0.174, p=0.063$, $\mathrm{p}=0.075$, and $\mathrm{p}=0.431$, respectively) (Table 2 ).

The patient group that was classified according to the diagnosis included $28 \%(n=55)$ NSTEMI, 28\% $(n=55)$ STEMI, 24\% $(n=48)$ stable angina, $16 \%(n=32)$ USAP, and $4 \%(n=9)$ pulmonary embolism. Sixteen (7\%) patients included in the study died during the course of hospitalization, which was statistically significantly different among the study groups $(p=0.024)$. The mortality rate in Group 1 was $10.6 \%$, and no mortality was observed in Group 3 (Table 2).

A significant difference was observed among the groups with regard to NGAL, CK-MB, and troponin I levels $(p<0.001, p<0.001$, and $p<0.001$, respectively). However, no difference was observed among the groups with regard to PTX-3 levels ( $p=0.978$ ) (Figure 1).

Paired comparisons were made among the groups. NGAL levels were determined to be significantly higher in Group 3 than in groups 


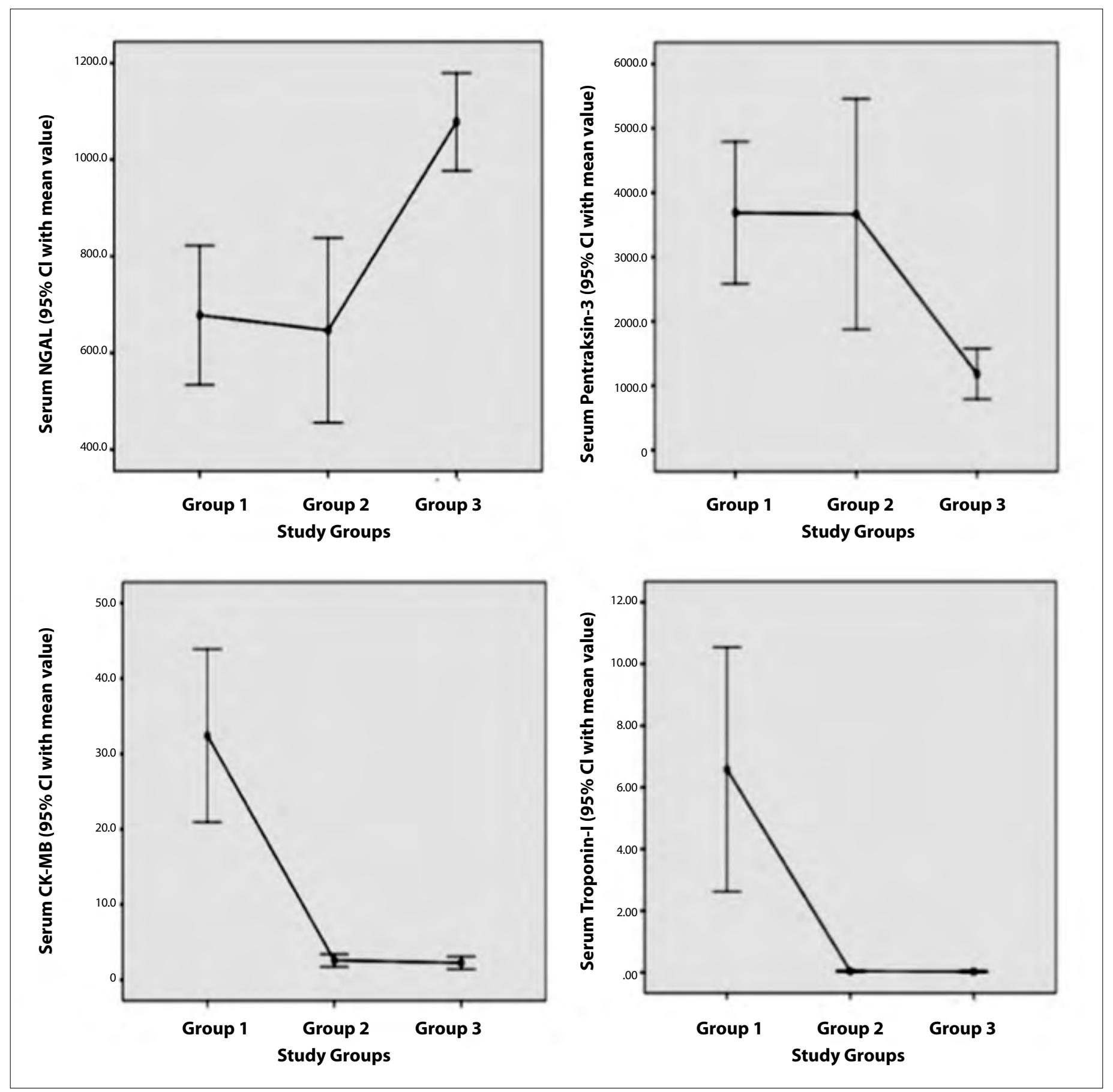

Figure 1. Comparison of the values of groups NGAL, pentraxin-3, CK-MB and troponin I

1 and $2(p<0.001$ and $p=0.003$, respectively). No difference was observed between groups 1 and 2 with regard to NGAL level $(p=0.270)$. CK-MB levels were significantly higher in Group 1 than group 2 and 3 $(p<0.001)$. No difference was observed between groups 2 and 3 with regard to CK-MB levels $(p=0.810)$. Troponin I levels were significantly higher in Group 1 than in groups 2 and $3(p<0.001$ and $p<0.001$, respectively). No difference was observed between groups 2 and 3 with regard to Troponin I levels ( $p=0.675$ ) (Table 2 ).

The study groups were classified as "survival" and "non-survival" groups according to in-hospital mortality (Table 3 ). The mean age of the patients in the non-survival group was significantly higher $(p<0.001)$. No difference was observed between the groups with regard to gender or comorbidity $(p=0.560$ and $p=0.540$, respectively). No difference was observed between the groups with regard to NGAL and PTX-3 levels, whereas a significant difference was determined for CK-MB and troponin I levels, which were higher in the non-survival group ( $p=0.547$ and $p=0.973$ vs. $p=0.001$ and $p<0.001$, respectively) (Table 3 ).

When the cardiac biomarkers were evaluated with regard to correlation, a significant correlation was observed only between CK-MB and troponin I $(r=0.723, p<0.001)$. No correlation was determined between the other biomarkers (NGAL and PTX-3). 
Table 2. Distribution of gender, age, comorbidities results among the study groups

\begin{tabular}{|c|c|c|c|c|c|}
\hline $\begin{array}{l}\text { Groups } \\
\text { Parameters }\end{array}$ & $\begin{array}{l}\text { All Groups } \\
(\mathbf{n}=\mathbf{2 2 9})\end{array}$ & $\begin{array}{l}\text { Group } 1 \\
(n=142)\end{array}$ & $\begin{array}{c}\text { Group } 2 \\
(n=57)\end{array}$ & $\begin{array}{c}\text { Group } 3 \\
(n=30)\end{array}$ & $\mathbf{p}$ \\
\hline Age (Mean value \pm standart deviation) & $60.48 \pm 14.84$ & $63.11 \pm 13.67$ & $53.82 \pm 15.78$ & $60.67 \pm 14.82$ & 0.001 \\
\hline \multicolumn{6}{|l|}{ Gender $^{\alpha}$} \\
\hline Male & $158(69)$ & $102(71.8)$ & $35(61.4)$ & $21(70)$ & \multirow[t]{2}{*}{0.353} \\
\hline Female & $71(31)$ & $40(28.2)$ & $22(38.6)$ & $9(30)$ & \\
\hline \multicolumn{6}{|l|}{ Comorbidity $^{a}$} \\
\hline Yes & $156(68.1)$ & $109(76.8)$ & $33(57.9)$ & $14(46.7)$ & \multirow[t]{2}{*}{0.001} \\
\hline No & $73(31.9)$ & $33(23.2)$ & $24(42.1)$ & $16(52.3)$ & \\
\hline \multicolumn{6}{|l|}{$\mathrm{ASCD}^{\alpha}$} \\
\hline Yes & $101(44.1)$ & $70(49.3)$ & $25(43.9)$ & $6(20)$ & \multirow[t]{2}{*}{0.013} \\
\hline No & $128(55.9)$ & $72(50.7)$ & $32(56.1)$ & $24(80)$ & \\
\hline \multicolumn{6}{|l|}{ DMa } \\
\hline Yes & $37(16.2)$ & $28(19.7)$ & $6(10.5)$ & $3(10)$ & \multirow[t]{2}{*}{0.174} \\
\hline No & $192(83.8)$ & $114(80.3)$ & $51(89.5)$ & $27(90)$ & \\
\hline \multicolumn{6}{|l|}{ Hypertension $^{a}$} \\
\hline Yes & $97(42.4)$ & $68(47.9 \%)$ & $21(36.8 \%)$ & $8(26.7 \%)$ & \multirow[t]{2}{*}{0.063} \\
\hline No & $132(57.6)$ & $74(52.1 \%)$ & $36(63.2 \%)$ & $22(73.3 \%)$ & \\
\hline \multicolumn{6}{|l|}{ Hyperlipidemia $^{\alpha}$} \\
\hline Yes & 27 (11.8) & $22(15.5)$ & $4(7)$ & $1(3.3)$ & \multirow[t]{2}{*}{0.075} \\
\hline No & $202(88.2)$ & $120(84.5)$ & $53(93)$ & $29(96.7)$ & \\
\hline \multicolumn{6}{|l|}{ Cigarette smoking $^{a}$} \\
\hline Yes & $69(30.1)$ & $45(31.7)$ & $18(31.6)$ & $6(20)$ & \multirow[t]{2}{*}{0.431} \\
\hline No & $160(69.9)$ & $97(68.3)$ & $39(68.4)$ & $24(80)$ & \\
\hline \multicolumn{6}{|l|}{ In-hospital mortality ${ }^{a}$} \\
\hline Survival & $213(93)$ & $127(89.4)$ & $56(98.2)$ & $30(100)$ & \multirow[t]{2}{*}{0.024} \\
\hline Non-survival & $16(7)$ & 15 (10.6) & $1(1.8)$ & $0(0)$ & \\
\hline \multicolumn{6}{|l|}{ Biomarkers $^{\beta}$} \\
\hline NGAL & $223(33.5-4974.4)$ & $171.55(33.5-4974.4)$ & $211.1(39.6-3012.8)$ & $1099.64(513.7-1568.6)$ & $<0.001$ \\
\hline PTX-3 & $707.75(13.7-21.000)$ & $709.51(13.7-21.000)$ & $705.98(18.9-21.000)$ & $916.46(308-4789.3)$ & 0.978 \\
\hline CK-MB & $2.6(0.2-299)$ & $4.2(0.6-299)$ & $1.8(0.2-20.5)$ & $1.6(0.8-13.1)$ & $<0.001$ \\
\hline Tn-I & $0.03(0.01-198)$ & $0.14(0.01-198)$ & $0.01(0.01-0.51)$ & $0.01(0.01-0.4)$ & $<0.001$ \\
\hline \multicolumn{6}{|c|}{$\begin{array}{l}\text { ASCD: atherosclerotic cardiac disease; CK-MB: creatine kinase-MB fraction; DM: diabetes mellitus; NGAL: neutrophil gelatinase associated lipocalin; PTX-3: pentraxin3; Tn-I: troponinl } \\
\text { aDescribed by number ( } n \text { ) and percentage (\%) } \\
\text { BDescribed by median value (minimum-maximum values) }\end{array}$} \\
\hline
\end{tabular}

The ROC curve of NGAL revealed an area under the curve (AUC) value of $0.729(p<0.001)$ (Figure 2$)$. The sensitivity, specificity, and accuracy of NGAL were $62 \%, 35 \%$, and $54 \%$, respectively, when the optimal threshold value was accepted as $502.1 \mathrm{ng} / \mathrm{mL}$.

\section{Discussion}

Despite advances in the diagnosis and treatment of ACS, the mortality, hospitalization, and recurrent infarction rates among patients with ACS remain high (2). Many biomarkers are being used and tested to perform risk analysis for diagnosing ACS that would result in early treatment. Cardiac troponins have high sensitivity and specificity in the diagnosis of myocardial injury. It should not be forgotten that cardiac troponins are currently used as the gold standard. However, an elevation in their levels may be observed in many situations other than cardiac events (17). In light of this information, new biomarkers are required.

One of the important risk factors for ACS is age. The mean ages of patients were $62.6 \pm 13,62.1 \pm 12$, and $62.83 \pm 12.9$ years in the studies by Leurent et al. (19), Ariza-Sole et al. (18), and Salama 
Table 3. Comparison of serum biomarkers between survival and non-survival groups according to the in-hospital mortality

\begin{tabular}{|c|c|c|c|}
\hline $\begin{array}{l}\text { Groups } \\
\text { Parameters }\end{array}$ & $\begin{array}{l}\text { Survival } \\
\text { group } \\
(\mathbf{n}=213)\end{array}$ & $\begin{array}{l}\text { Non-survival } \\
\text { group } \\
(n=16)\end{array}$ & $\mathbf{p}$ \\
\hline $\begin{array}{l}\text { Age (Mean value } \pm \\
\text { standard elevation) }\end{array}$ & $59.25 \pm 14.40$ & $76.81 \pm 10.48$ & $<0.001$ \\
\hline \multicolumn{4}{|l|}{ Gender $^{\alpha}$} \\
\hline Male & $148(69.5)$ & $10(62.5)$ & \multirow{2}{*}{0.560} \\
\hline Female & $65(30.5)$ & $6(37.5)$ & \\
\hline \multicolumn{4}{|l|}{ Comorbidity $^{a}$} \\
\hline Yes & $144(67.6)$ & $12(75)$ & \multirow{2}{*}{0.540} \\
\hline No & $69(32.4)$ & $4(25)$ & \\
\hline \multicolumn{4}{|l|}{ Biomarkers $^{\beta}$} \\
\hline NGAL & $\begin{array}{c}226.3 \\
(33.5-4974.4)\end{array}$ & $\begin{array}{c}221.3 \\
(51.6-2317.5)\end{array}$ & 0.547 \\
\hline PTX-3 & $\begin{array}{c}714.79 \\
(13.7-21000)\end{array}$ & $\begin{array}{c}616.2 \\
(113.5-21000)\end{array}$ & 0.973 \\
\hline CK-MB & $2.5(0.2-299)$ & $24.55(1.9-238.6)$ & 0.001 \\
\hline Tn-I & $0.02(0.01-198)$ & $4.44(0.01-100)$ & $<0.001$ \\
\hline \multicolumn{4}{|c|}{$\begin{array}{l}\text { CK-MB: creatine kinase-MB fraction; NGAL: neutrophil gelatinase-associated lipocalin; } \\
\text { PTX-3: pentraxin3; } \mathrm{Tn}-\mathrm{I} \text { : troponin I } \\
\text { aDescribed by number ( } \mathrm{n} \text { ) and percentage (\%) } \\
{ }^{\text {BD }} \text { Described by median value (minimum-maximum values) }\end{array}$} \\
\hline
\end{tabular}

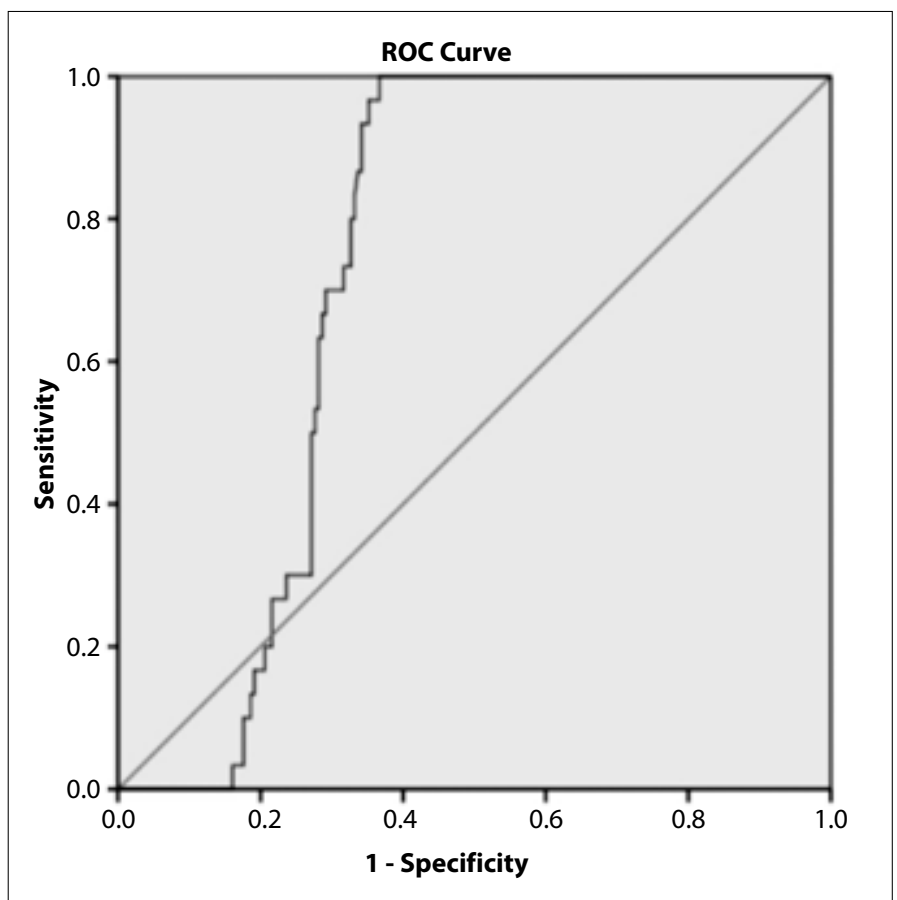

Figure 2. The ROC Curve of NGAL

et al. (20), respectively. In our study, the mean age of the patients was $63.11 \pm 13.67$ years, which was similar to those reported in the literature.

Various rates of STEMI, NSTEMI, and USAP have been reported in case series published in the literature. In a study including patients presenting to the emergency unit with a complaint of chest pain, $41 \%$ of patients had NSTEMI and STEMI, $27 \%$ had USAP, and $32 \%$ had non-cardiac chest pain; in another study, one-third of the patients with ACS had STEMI and the remaining had NSTEMI and USAP (21, 22). In other studies, various rates have been reported for patients with ACS, such as 54\%-61\% in NSTEMI and 33\%-45.6\% in STEMI (20, $23,24)$. In our study, $39 \%$ of the patients with ACS had NSTEMI, 39\% had STEMI, and $22 \%$ had USAP.

Hasdai et al. (25) reported the coronary cardiac disease-related mortality rate to be $20 \%$ in the $35-55$-year age group. In another study, the in-hospital mortality rate among patients with ACS was $4 \%$ (26). In another study investigating mortality rates in ACS, the in-hospital mortality rate was $20 \%$ for those having STEMI and $10 \%$ for those having NSTEMI (27). In our study, the in-hospital mortality rates were $7.2 \%$ and $6.3 \%$ for patients having STEMI and NSTEMI, respectively.

PTX-3 is an acute-phase reactant that has recently been discovered. Atherosclerosis is known to develop as a reason for an inflammatory process. It was determined that endothelial cells and macrophages are involved in the basic formation of atherosclerosis and that PTX-3 is secreted from atherosclerotic lesions (28). In the study by Matsui et al. (29), elevated serum PTX-3 levels were related to USAP, STEMI, NSTEMI, cardiac failure, and negative cardiovascular events. Ustundag et al. (30) determined the sensitivity and specificity of PTX-3 levels analyzed within the first $6 \mathrm{~h}$ to be $98.5 \%$ and $92.3 \%$, respectively, in patients with ACS. Buyukkaya et al. (31) investigated PTX-3 levels in patients with cardiac syndrome $X$ and determined a significantly higher PTX-3 level in the study group than in the control group. In many studies conducted on patients with vascular diseases, mortality was seen to have correlated to elevated PTX-3 levels (32, 33). In the study by Latini et al. (32), elevated PTX-3 levels have been suggested to be related to 3-month mortality in patients with MI. However, in our study, serum PTX-3 levels observed in the groups were investigated with regard to the diagnosis and in-hospital mortality, and no significant difference was observed.

Risk factors and correlations for leukocyte activation in atherosclerosis have also been reported in a study, a correlation has been demonstrated between symptomatic cardiovascular diseases and elevated NGAL levels; on the contrary, plasma NGAL levels and non-symptomatic cardiovascular diseases have been demonstrated to be not correlated (34). In another study, the group of patients with CAD confirmed via angiography was compared to the groups of patients with normal coronary arteries, and serum NGAL levels were found to be significantly elevated in the presence of CAD (35). In a similar study, 47 patients with NSTEMI confirmed via angiography were compared to 45 control patients with stable angina (having undergone coronary angiography and determined to have normal coronary arteries), and NGAL levels were positively correlated to lesion complexity and the diffusiveness of CAD in patients with NSTEMI. It was concluded that serum NGAL levels on admission are related to the increased atherosclerotic load in patients with Non-ST elevated Acute Coronary Syndrome(NSTE-ACS)(36).

In the study by Choi et al. (37), serum NGAL levels were determined to be significantly higher in patients with CAD than in the healthy population. Similarly in another study, serum NGAL levels showed an increasing tendency in CAD and AMI, although this was not significant. In the study by Arslan et al. (38) that compared patients with stable CAD and AMI, significantly higher plasma NGAL 
levels were detected in the AMI group; however, no difference was found between STEMI and NSTEMI. It was concluded that NGAL NGAL levels are more successful indicator in detecting MI than other inflammatory markers. In our study, NGAL levels were significantly lower in the ACS and non-ACS patient groups (Group 1 and 2) than in the control group, and no difference was detected between the ACS and non-ACS groups.

According to the risk classification of the American College of Cardiology/American Heart Association, a cardiac troponin I level between 0.1 and $1.5 \mathrm{ng} / \mathrm{mL}$ indicates a moderate risk, and a level over $1.5 \mathrm{ng} / \mathrm{mL}$ indicates a high risk in patients with NSTEMI (39). In another study, troponin levels were observed to increase within 2-3 $\mathrm{h}$ after admission to the ED in $80 \%$ of patients with $\mathrm{MI}$, and the levels of CK-MB and other cardiac biomarkers were found to start increasing within 6-9 h (40). Similarly, in our study, CK-MB and troponin I had an elevated course in the patient group (group 1 patients), which was statistically significant.

\section{Study limitations}

Our study was a single-center prospective study. The control group included patients who had presented to our emergency unit with complaints other than chest pain and whose diagnosis did not comprise chest pain in the differential diagnosis. The amount of time between the onset of chest pain and the time of blood sampling could not be determined. The number of patients was also limited.

\section{Conclusion}

In conclusion, the data obtained in our study indicate that NGAL and PTX-3 are not effective biomarkers in the differential diagnosis of chest pain or the prediction of mortality in ACS. This conclusion should be evaluated considering the limitations of our study. The outcomes obtained in this study confirm the use of CK-MB and troponin I, which are used in daily practice, as reliable biomarkers in the differential diagnosis and in the prediction of mortality.

Ethics Committee Approval: Ethics committee approval was received for this study from the ethics committee of Necmettin Erbakan University Meram School of Medicine (03.01.2014, Decision No: 2014-570).

Informed Consent: Written informed consent was obtained from patients who participated in this study.

Peer-review: Externally peer-reviewed.

Conflict of Interest: No conflict of interest was declared by the authors.

Financial Disclosure: This study was supported by Necmettin Erbakan University Scientific Research Project (BAP) (project no: 14158005).

\section{References}

1. Solinas L, Raucci R, Terrazzino S, Moscariello F, Pertoldi F, Vajto S, et al. Prevalence, clinical characteristics, resource utilization and outcome of patients with acute chest pain in the emergency department. A multicenter, prospective, observational study in north-eastern Italy. Ital Heart J 2003; 4: 318-24.
2. Task Force for Diagnosis and Treatment of Non-ST-Segment Elevation Acute Coronary Syndromes of European Society of Cardiology, Bassand JP, Hamm CW, Ardissino D, Boersma E, Budaj A, Fernández-Avilés F, et al. Guidelines for the diagnosis and treatment of non-ST-segment elevation acute coronary syndromes. Eur Heart J 2007; 28: 1598-660. [CrossRef]

3. Pope JH, Aufderheide TP, Ruthazer R, Woolard RH, Feldman JA, Beshansky JR, et al. Missed diagnoses of acute cardiac ischemia in the emergency department. N Engl J Med 2000; 342: 1163-70. [CrossRef]

4. Khan NA, Hemmelgarn BR, Tonelli M, Thompson CR, Levin A. Prognostic value of troponin $T$ and $I$ among asymptomatic patients with end stage renal disease: a meta-analysis. Circulation 2005; 112: 3088-96. [CrossRef]

5. Vasile VC, Babuin L, Rio Perez JA, Alegria JR, Song LM, Chai HS, et al. Long term prognostic significance of elevated cardiac troponin levels in critically ill patients with acute gastrointestinal bleeding. Crit Care Med 2009; 37: 140-7. [CrossRef]

6. Vasile VC, Chai HS, Khambatta S, Afessa B, Jaffe AS. Significance of elevated cardiac troponin T levels in critically ill patients with acute respiratory disease. Am J Med 2010; 123: 1049-58. [CrossRef]

7. Batal O, Jentzer J, Balaney B, Kolia N, Hickey G, Dardari Z, et al. The prognostic significance of troponin I elevation in acute ischemic stroke. J Crit Care 2016; 31: 41-7. [CrossRef]

8. Zhang L, Wang Z, Qi S. Cardiac troponin elevation and outcome after subarachnoid hemorrhage: a systematic review and meta-analysis. J Stroke Cerebrovasc Dis 2015; 24: 2375-84. [CrossRef]

9. Freitas $C$, Larrivée B, Eichmann A. Netrins and UNC5 receptors in angiogenesis. Angiogenesis 2008; 11:23-9. [CrossRef]

10. Walz A, Baggiolini M. Generation of the neutrophil-activating peptide NAP-2 from platelet basic protein or connective tissue-activating peptide III through monocyte proteases. J Exp Med 1990; 171: 449 54. [CrossRef]

11. Peri G, Introna M, Corradi D, lacuitti G, Signorini S, Avanzini F, et al. PTX3, a prototypic long pentraxin, is an early indicator of acute myocardial infarction in humans. Circulation 2000; 102: 636-41. [CrossRef]

12. Eagan TM, Damås JK, Ueland T, Voll-Aanerud M, Mollnes TE, Hardie JA, et al. Neutrophil gelatinase-associated lipocalin: a biomarker in COPD. Chest 2010; 138: 888-95. [CrossRef]

13. Nielsen BS, Borregaard N, Bundgaard JR, Timshel S, Sehested M, Kjeldsen $L$. Induction of NGAL synthesis in epithelial cells of human colorectal neoplasia and inflammatory bowel diseases. Gut 1996; 38: 414-20. [CrossRef]

14. Flo TH, Smith KD, Sato S, Rodriguez DJ, Holmes MA, Strong RK, et al. Lipocalin 2 mediates an innate immune response to bacterial infection by sequestrating iron. Nature 2004; 432: 917-21. [CrossRef]

15. Xu S, Venge P. Lipocalins as biochemical markers of disease. Biochim Biophys Acta 2000; 1482: 298-307. [CrossRef]

16. Bolignano D, Coppolino G, Lacquaniti A, Buemi M. From kidney to cardiovascular diseases: NGAL as a biomarker beyond the confines of nephrology. Eur J Clin Invest 2010; 40: 273-6. [CrossRef]

17. Hamm C, Heeschen C, Falk E, Fox KAA. Acute coronary syndromes: pathophysiology, diagnosis and risk stratification. In: Camm AJ, Luescher TF, Serruys PW, ed. The ESC Textbook of Cardiovascular Medicine. Oxford: UK, Blackwell Publishing; 2006. p333-66.

18. Ariza-Solé A, Formiga F, Lorente V, Sánchez-Salado JC, Sánchez-Elvira $\mathrm{G}$, Roura $\mathrm{G}$, et al. Efficacy of bleeding risk scores in elderly patients with acute coronary syndromes. Rev Esp Cardiol (Engl Ed). 2014; 67: 463-70. [CrossRef]

19. Leurent G, Garlantézec R, Auffret V, Hacot JP, Coudert I, Filippi E, et al. Gender differences in presentation, management and in hospital out come in patients with ST-segment elevation myocardial infarction: Data from 5000 patients included in the ORBI prospective French regional registry. Arch Cardiovasc Dis 2014; 107: 291-8. [CrossRef]

20. Salama M, Çakmak H A, Coşansu K, İitimur B, Karadağ B, Enar RAkut koroner sendromlarda standart risk skorlamalarıly birlikte gelişteki NT-proBNP düzeyinin 6 aylık mortalite ve morbiditeye etkileri. Turk Kardiyol Dern Ars 2010; Suppl 2: 136. 
21. Gay PC, Nishimura RA, Roth CS, Evans WE, Zinsmeister AR, Kottke BA. Lipoprotein analysis in the evaluation of chest pain in the emergency department. Mayo Clin Proc 1991; 66: 885-91. [CrossRef]

22. Bugiardini R. Risk stratification in acute coronary syndrome: focus on unstable angina non-ST segment elevation myocardial infarction. Heart 2004; 90: 729-31. [CrossRef]

23. El-Menyar A, Zubaid M, Shehab A, Bulbanat B, Albustani N, Alenezi F, et al. Prevalence and impact of cardiovascular risk factors among patients presenting with acute coronary syndrome in the Middle East. Clin Cardiol 2011; 34: 51-8. [CrossRef]

24. Stähli BE, Yonekawa K, Altwegg LA, Wyss C, Hof D, Fischbacher P, et al. Clinical criteria replenish high-sensitive troponin and inflammatory markers in the stratification of patients with suspected acute coronary syndrome. PLos One 2014; 3: 9: e98626.

25. Hasdai D, Topol EJ, Kilaru R, Battler A, Harrington RA, Vahanian A, et al. Frequency, patient characteristics, and outcomes of mild-to-moderate heart failure complicating ST-segment elevation acute myocardial infarction: lessons from 4 international fibrinolytic therapy trials. Am Heart J 2003; 145: 73-9. [CrossRef]

26. Aragam KG, Tamhane UU, Kline-Rogers E, Li J, Fox KA, Goodman SG, et al. Does simplicity compromise accuracy in acs risk prediction? A retrospective analysis of the TIMI and GRACE risk scores. PLoS One 2009; 4: e7947. [CrossRef]

27. Wiviott SD, Morrow DA, Giugliano RP, Frederick CH, McCabe $\mathrm{CP}$, Cannon $\mathrm{EM}$, et al. Performance of the thrombolysis in myocardial infarction risk index for early acute coronary syndrome in the National Registry of Myocardial Infarction: a simple risk index predicts mortality in both ST and non-ST elevation myocardial infarction. J Am Coll Cardiol 2003; 41: 365-6. [CrossRef]

28. Lusis AJ. Atherosclerosis. Nature 2000; 407: 233-41. [CrossRef]

29. Matsui S, Ishii J, Kitagawa F, Kuno A, Hattori K, Ishikawa M, et al. Pentraxin 3 in unstable angina and non-ST-segment elevation myocardial infarction. Atherosclerosis 2010; 210: 220-5. [CrossRef]

30. Ustundag M, Orak M, Güloğlu C, Sayhan M B, Alyan O, Kale E. Comparative diagnostic accuracy of serum levels of neutrophil activating peptide- 2 and pentraxin-3 versus troponin-I in acute coronary syndrome. Anadolu Kardiyol Derg 2011; 11: 588-94. [CrossRef]
31. Büyükkaya $E$, Karakaş $M F$, Kurt $M$, Motor $S$, Akçay $A B$, Büyükkaya $S$, et al. The serum pentraxin-3 is elevated in patients with cardiac syndrome $X$. Turk Kardiyol Dern Ars 2013; 41: 290-5. [CrossRef]

32. Latini R, Maggioni AP, Peri G, Gonzini L, Lucci D, Mocarelli P, et al. Prognostic significance of the long pentraxin PTX3 in acute myocardial infarction. Circulation 2004: 110: 2349-54. [CrossRef]

33. Suzuki S, Takeishi Y, Niizeki T, Koyama Y, Kitahara T, Sasaki T, et al. Pentraxin 3, a new marker for vascular inflammation, predicts adverse clinical outcomes in patients with heart failure. Am Heart J 2008; 155: 75-81. [CrossRef]

34. Elneihoum AM, Falke P, Hedblad B, Lindgärde F, Ohlsson K. Leukocyte activation in atherosclerosis: correlation with risk factors. Atherosclerosis 1997; 131: 79-84. [CrossRef]

35. Zografos T, Haliassos A, Korovesis S, Giazitzoglou E, Voridis E, Katritsis D. Association of neutrophil gelatinase-associated lipocalin with the severity of coronary artery disease. Am J Cardiol 2009; 104: 917-20. [CrossRef]

36. Soylu K, Aksan G, Nar G, Özdemir M, Gülel O, Inci S, et al. Serum neutrophil gelatinase-associated lipocalin levels are correlated with the complexity and severity of atherosclerosis in acute coronary syndrome. Anatol J Cardiol 2015; 15: 450-5. [CrossRef]

37. Choi KM, Lee JS, Kim EJ, Baik SH, Seo HS, Choi DS, et al. Implication of lipocalin-2 and visfatin levels in patients with coronary heart disease. Eur $J$ Endocrinol 2008; 158: 203-7. [CrossRef]

38. Sahinarslan A, Kocaman SA, Bas D, Akyel A, Ercin U, Zengin O, et al. Plasma neutrophil gelatinase-associated lipocalin levels in acute myocardial infarction and stable coronary artery disease. Coron Artery Dis 2011; 22: 333-8. [CrossRef]

39. Braunwald E, Antman EM, Beasley JW, Califf RM, Cheitlin MD, Hochman JS, et al. ACC/AHA 2002 guideline update for the management of patients withunstable angina and non-ST segment elevation myocardial infarction-summary article: a report of the American College of Cardiology/American Heart Association task force on practice guidelines (Committee on the Management of Patients With Unstable Angina). J Am Coll Cardiol 2002; 40: 1366-74. [CrossRef]

40. Thygesen K, Alpert JS, Jaffe AS, Simoons ML, Chaitman BR, White HD, et al. Third universal definition of myocardial infarction. Eur Heart J. 2012; 33: 2551-67. [CrossRef] 